\title{
FISCAL RESPONSIBILITY LAW AND SUBNATIONAL FINANCE IN INDIA - AN ANALYSIS OF ASSAM'S FISCAL SCENARIO
}

\author{
Santosh Borkakati ${ }^{*}$ and Konthoujam Gyanendra Singh \\ Department of Basic Science and Humanities \& Social Sciences, National Institute of Technology, \\ Mizoram, India
}

Fiscal responsibility law has become an important instrument for better fiscal management and ensuring fiscal discipline, particularly so in the federal countries where their subnational governments often indulge in fiscal indiscipline. In 2003, India adopted the Fiscal Responsibility and Budget Management Act for rule-based fiscal discipline, and the states of India were also asked to adopt their own fiscal rule legislation in line with the legislation adopted by the central government. As a fiscally weak Indian state, Assam enacted the Assam Fiscal Responsibility and Budget Management (AFRBM) Act in 2005 for better fiscal management. The paper attempts to examine the impact of the AFRBM Act on the fiscal performance of the state by analyzing the dynamics of the fiscal variables in the pre- and post-AFRBM Act periods. The study finds that the state has improved its fiscal condition after the introduction of the AFRBM Act, even though it has remained prone to fiscal shocks.

Keywords: fiscal rules, subnational finance, fiscal deficit, fiscal stability

JEL Classification: E62, H30, H61, H70

\section{INTRODUCTION}

The fiscal rule legislation has become an important fiscal reform measure in recent decades. Countries around the world, such as Australia, the United Kingdom, Brazil, Canada, Mexico, the United States and so on have adopted the varying levels of fiscal

* Correspondence to: S. Borkakati, Department of Basic Science and Humanities \& Social Sciences, National Institute of Technology, Mizoram, India; e-mail: sborkakati8@gmail.com rules. Fiscal rules are the law provisions intended to put constraints on the government with respect to the fiscal policy (Grembi, Nannicini \& Troiano, 2016). Fiscal rules may come in various forms, but they all have the common feature of imposing numerical limitations, such as the ratio of a debt to the GDP, a limit to a fiscal deficit and so on. Governments have the tendency to spend more, which often leads to fiscal deterioration and creates serious fiscal instability at times. The theoretical background of fiscal rules implies the fact that there is a deficit bias and a common pool problem (Wyplosz, 2012). Governments shift the burden of a 
debt to future generations and politicians have the tendency to provide public largesse. The support for fiscal rules rests on the premise that they can help oblige policymakers to commit themselves to a sound fiscal policy (Tapp, 2013). Fiscal laws may restrict decision-makers from adopting politically beneficial policies and improve budgetary outcomes. The use of fiscal rules to maintain fiscal discipline and fiscal consolidation has been advocated by organizations such as the IMF (2009) and the OECD (2011).

Since the 1980s, India has been experiencing the gradual deterioration of the fiscal condition of both the central government and the state governments, the fiscal scenario having become particularly troublesome in the 1990s, when the states were experiencing sharp fiscal deterioration with the rising deficits and debt burden (Lahiri, 2000; World Bank, 2004; Singh, Prasad, Sharma \& Reddy, 2017). The fiscal deficit of the Centre, which was 5.7 percent in the period 1980-81, grew to 7.8 percent in the period 199091. The fiscal deficit of all the states, which amounted to 2.57 percent of the GDP in the period 1980-81, rose to 3.30 percent in the period 1999-91, and 4.72 percent in the period 1999-2000, and the combined fiscal deficit of the Centre and the States in the period 19992000 stood at 9.5 percent of the GDP (Reserve Bank of India, 2005). The outstanding debt of the states increased from 19.4 percent of the GDP in the period 1990-91 to 23.1 percent in the period 2000-01, and interest payment to the total expenditure of the states also rose from 13 percent to 21.6 percent (Rao, 2004) over the same period.

In response to the worsening fiscal condition, the Government of India has undertaken major fiscal restructuring since the 1990s through reforms in direct and indirect taxes, expenditure restructuring, the disinvestment of the undertakings of the public sector and debt management (Chakraborty, Mukherjee \& Amarnath, 2009). Fiscal reform measures were also initiated by the states through reforms in the states' taxes, restructuring expenditure, reducing government subsidies, a reform in the power sector and so on. The most significant fiscal reform measure, however, was the Fiscal Responsibility and Budget Management (FRBM) Act ${ }^{1}$, enacted by the
Government of India in 2003. Like the Maastricht Treaty $^{2}$ and the United Kingdom's Golden Rule ${ }^{3}$, the FRBM Act required that the Central Government of India should keep the budget deficit of the Government and the public debt within specified limits (Maurya, 2013). The underlying motive was that the fiscal rule measures adopted through the legislation were more likely to be followed than the fiscal correction measures through executive action. The FRBM Act of 2003 mandated that the Central Government of India should reduce its fiscal deficit to 3 percent of the GDP and eliminate the revenue deficit completely by 2008-09 (Singh et al, 2017). The state governments were asked to enact their own fiscal rule legislations in line with the FRBM Act. Like the other states of India, Assam adopted its own version of the FRBM Act and implemented the Assam Fiscal Responsibility and Budget Management (AFRBM) $\mathrm{Act}^{4}$ in 2005 in order to improve and stabilize the fiscal position of the state.

This paper attempts to find the impact of the AFRBM Act on the fiscal performance of the State of Assam. The remainder of the article is structured into five sections. Apart from the Introduction, Section Two is a presentation of a literature review. The data and the methodology are discussed in Section Three. Section Four is an analysis of the state's revenue, expenditure, debt and deficit indicators. The last, Section Five, ends the paper providing appropriate remarks.

\section{LITERATURE REVIEW}

Many cross-country and country-specific studies have found a strong association between fiscal rules and better fiscal results (Guichard, Kennedy, Wurzel \& Andre, 2007; IMF, 2009). S. Krogstrup and S. Wälti (2008) found that fiscal rules improved fiscal discipline by keeping the budget deficit in check. However, it may also have a negative impact on beneficial productive public investment. S. Tapp (2013) found a significant relationship between a fiscal regulation and fiscal results for the Canadian provinces. He observed that the stronger the fiscal rules, the better the budget outcome. F. Heinemann, 
M. D. Moessinger and M. Yeter (2018) observed a significant constraining impact of fiscal rules on fiscal variables. They found the effect of fiscal rules more on the deficit indicators than on a debt, expenditure or revenue. Grembi et al (2016) found fiscal rules to be effective when accompanied by an enforcement mechanism and when governments demonstrate serious commitment. So, they suggested that designing fiscal rules should take into account political incentives in rules enforcement. A. Sacchi and S. Salotti (2015) studied the relationship between the discretionary fiscal policy and the macroeconomic stability of the 21 OECD countries for the period 19852012 and found that the adoption of strict fiscal rules could mitigate the problem of the output-destabilizing effect of the discretionary fiscal policy.

Some other authors are, however, skeptical about the effectiveness of fiscal rules. C. Wyplosz (2012) argued that fiscal rules might be ineffective in achieving fiscal discipline due to various policy and enforcement problems. G. Kopits (2012) opined that fiscal rules might compromise the fiscal sovereignty of states and rigid fiscal rules might do a lot of harm at the times of economic crises. L. Feld and G. Kirchgässner (2001) found that the existence of fiscal regulations in the Swiss Cantons did not have an impact on budgetary performance. M. U. Bergman and M. Hutchison (2015) observed that fiscal rules were only effective when governments work efficiently, whereas the same were less effective in developing countries, where the governance quality was low. M. Halac and P. Yared (2018) opine that fiscal rules are not an unmixed blessing and that there is an ongoing trade-off between commitment and the flexibility of fiscal rules. Tighter fiscal rules can limit policymakers' distorted incentives, but they cannot spell out policy measures for every single shock or contingency. Flexible rules will allow policymakers to efficiently deal with the unforeseen contingencies, whereas flexibility may lead to fiscal indiscipline. So, the more flexible the rules are, the higher the risk of fiscal distortion, and the more stringent the rules, the lesser the ability to respond to the possible contingencies. Therefore, the enactment of a fiscal responsibility legislation is not sufficient. It has to be effectively implemented so as to ensure fiscal discipline and fiscal consolidation
(Sawhney, 2018). According to A. Afonso and J. T. Jalles (2019), fiscal rules help bring down the costs of public borrowing and lower the levels of the public debt to the GDP. W. H. Reuter (2015) argues that, even though fiscal rules are often not sincerely adhered to, they do serve as a benchmark to the government, which a fiscal policy is focused on.

There have been mixed reviews of the effect of the FRBM Act on the fiscal improvement of the Indian Central Government and State Governments. R. K. Pattnaik (2016) observed that, although the fiscal rule legislation had a positive effect on the fiscal position, on the one hand, the performance of such fiscal improvements was disappointing both in the Centre and in the States, on the other. Although the major deficit indicators had shown a declining trend after the implementation of the FRBM Act, no significant effect had been made on the fiscal deficit, and the ratio of the debt to the GDP had only marginally declined. They found a declining trend in capital expenditure against an increasing trend of revenue expenditure instead. B. M. Misra and J. K. Khundrakpam (2008) found that the improvement of the deficit indicators in the post-FRBM Act period was mainly due to the high growth rate of the Indian economy, which had improved revenue collection. Singh et al (2017) found that the Central Government had not sincerely followed the fiscal regulations, particularly not so since the 2008 global financial crisis, and that the FRBM Act had been stalled four times since its introduction in 2003. Despite what, though the FRBM Act had shown a positive effect on the fiscal indicators, it had led to an increase in the off-budget liabilities which might increase the burden of the debt in the future.

Examining the impact of the fiscal rules on the states' finance, A. S. Simone and P. B. Topalova (2009) found that the FRBM Act had helped the states improve the fiscal situation and that the fiscal rules had been effective in controlling the debt and the expenditure. S. Badaik (2017) studied the effect of the FRBM Act on the Indian states' finance, having found that the legislations on fiscal responsibility were effective in reducing the revenue deficit, as well as the fiscal deficit, of the Indian states. He, however, suggested 
that an institutional states' fiscal performance monitoring mechanism should be developed. S. Raju (2008), P. Chakraborty and B. B. Dash (2013), N. K. Maurya (2013) and other authors found that the fiscal responsibility rules had helped the states improve their fiscal conditions. The Economic Survey of India for 2016-17, (Government of India, 2017) noted that the fiscal improvement of the states could not outrightly be solely credited to the fiscal rules. A large number of the exogenous factors, such as higher GDP growth, increased transfers from the Centre, reduced interest payments, etc. had helped the states reduce the deficits. With respect to Assam, P. Dutta and M. K. Dutta (2014) and N. A. Barua, N. Goswami and N. P. Dutta (2013) found improvements in the state's fiscal situation after the enactment of the AFRBM act, even though the state remained heavily dependent on central transfers.

According to the literature review, fiscal rules are found to be necessary in order to keep reminding policymakers of the fiscal responsibility although the effectiveness of and compliance with the fiscal rules are contested. The discussion allowed us to formulate the hypothesis of the conducted analysis, implying that fiscal responsibility rules have a positive impact on fiscal performance.

\section{DATA AND METHODOLOGY}

In the present study, Assam's fiscal scenario for the period from 1990-91 to 2016-17 is examined, dichotomizing it into the pre-AFRBM Act period (from 1990-91 to 2004-05) and the post-AFRBM Act period (from 2005-06 to 2016-17). The study was carried out by examining the dynamics of the fiscal variables in the observed period by using simple statistical measures.

The study is entirely based on the data obtained from the secondary sources. The relevant data were collected from the various statistical reports and publications of the Government of India, the Government of Assam and the Reserve Bank of India. The data on revenue, expenditure, the debt and the deficit were obtained from the Statistical Handbook of Assam (the issues from 1991 to 2016), published by the Directorate of Economics and Statistics, the Government of Assam; the Report of the Comptroller and Auditor General of India on the State of the Finance of Assam (the issues from 2002 to 2017); the Handbook on Statistics on Indian States (2018), published by the Reserve Bank of India. The data on the Gross State Domestic Product (GSDP) of Assam were obtained from the Central Statistical Organization of the Government of India.

\section{RESULTS AND DISCUSSION}

Assam's AFRBM Act was enacted for the main purpose of arresting the deteriorating fiscal situation of the state and consolidating the fiscal position. The Act only notes the aims of reducing the debt and the deficit, simultaneously intending to improve revenue collection and expenditure rationalization. Therefore, the impact of the AFRBM Act was examined by analyzing the trend and composition of the state's revenue, expenditure, debt and deficit.

\section{Revenue trend}

The Indian states' revenue receipts are broadly categorized into own revenue receipts and central transfers. The states' tax revenue and nontax revenue constitute the states' own revenue, whereas central transfers comprise the states' share in the central taxes and grants-in-aid from the Centre. In the postAFRBM period (from 2005-06 to 2016-17), the state's revenue receipts grew slightly higher at a compound annual growth rate (CAGR) 13.65 percent compared to the pre-AFRBM period (from 1990-91 to 2004-05), when the CAGR was 13.08 percent (Table 1). The growth trend of the different components of revenue reveals that the growth rate of the state's own-tax revenue significantly fell in the post-AFRBM period, which contributed to the fall in the growth rate of the state's own revenue. The state's share in the central taxes, however, markedly increased at the CAGR 18.72 percent during the post-AFRBM period against 
the CAGR 12.64 percent during the pre-AFRBM period. The post-AFRBM period witnessed a fall in the growth rate of own revenue, on the one hand, and an increase in the growth of central transfers, on the other.

The composition of Assam's revenue receipts shows that the share of the state's own revenue in the state's revenue receipt was only 39.26 percent in 1990-91, only to have declined to 33.38 percent in 2016-17 (in the post-AFRBM period - Figure 1). Accordingly, the share of the central transfers went up from 60.74 percent in 1990-91 to 66.62 percent in 2016-17. In comparison with all the other states, the State of Assam had a much lower share of own tax and own revenue in revenue receipt, which reflects the fact that, on revenue side, Assam was highly dependent on the transfers from the Centre, which dependence increased in the postAFRBM period.

During the post-AFRBM period, the state's own-revenue buoyancy and own-tax buoyancy deteriorated. The average own-tax buoyancy and own-revenue buoyancy during the pre-AFRBM period were 1.12 and 1.39 , respectively, which declined to 1.03 and 1.05 , respectively, during the post-AFRBM

Table 1 Assam's revenue receipt trend: Pre- and post-AFRBM periods (\%)

\begin{tabular}{|c|c|c|c|c|c|c|c|}
\hline Period & Tax revenue & $\begin{array}{l}\text { Non-tax } \\
\text { revenue }\end{array}$ & $\begin{array}{l}\text { Own } \\
\text { revenue }\end{array}$ & $\begin{array}{c}\text { Share in } \\
\text { central taxes }\end{array}$ & Grant-in-aid & $\begin{array}{l}\text { Central } \\
\text { transfers }\end{array}$ & $\begin{array}{l}\text { Total } \\
\text { revenue } \\
\text { receipt }\end{array}$ \\
\hline $\begin{array}{l}\text { *CAGR } \\
\text { pre- AFRBM } \\
\text { period }\end{array}$ & 14.25 & 10.11 & 12.83 & 12.64 & 13.71 & 13.24 & 13.08 \\
\hline $\begin{array}{l}{ }^{*} \text { CAGR } \\
\text { post- AFRBM } \\
\text { period }\end{array}$ & 12.73 & 10.45 & 12.07 & 18.72 & 10.27 & 14.56 & 13.65 \\
\hline
\end{tabular}

*CAGR = Compound Annual Growth Rate

Source: Government of Assam, 1991-2016; Reserve Bank of India, 2018

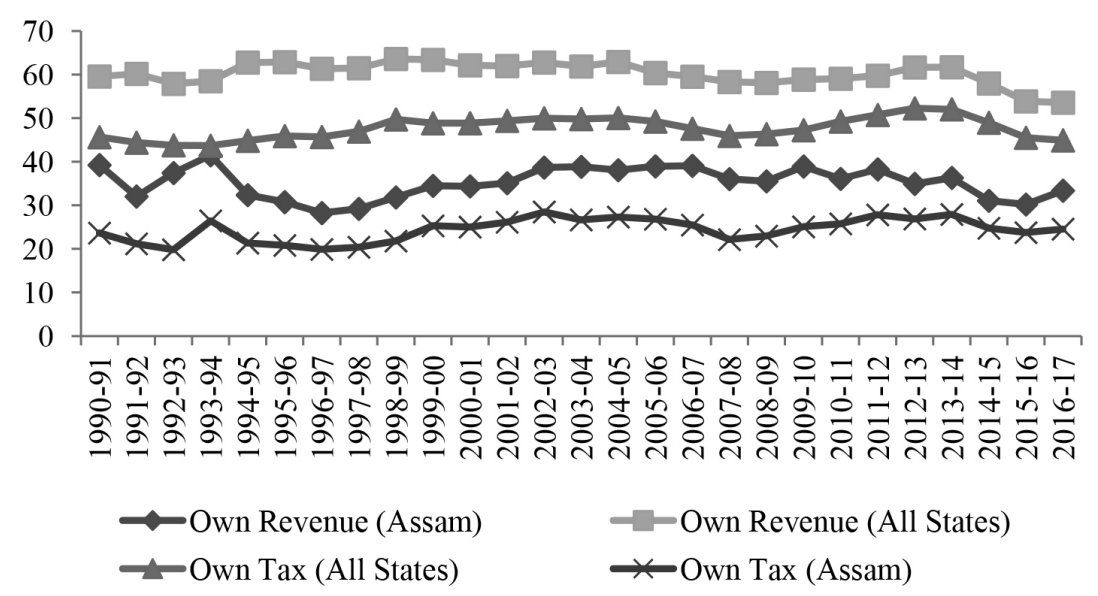

Figure 1 The contribution of the state's own tax revenue and the state's own revenue in revenue receipt: Assam and all the states (In percentage)

Source: Government of Assam, 1991-2016; Reserve Bank of India, 2018 
period (Table 2). However, the Own Tax/GSDP and Own Revenue/GSDP ratios showed an improvement in the post-AFRBM period (Figure 2).

Thus, the improvement on the revenue side of the state budget in the post-AFRBM period is a result of growing central transfers. The revenue effort of the state towards fiscal consolidation did not improve in the post-AFRBM period, but the state's dependence on central transfers rather increased.

\section{Expenditure trend and composition}

The total expenditure of the state is broadly categorized into revenue expenditure, capital outlay and the disbursement of loans and advances. The expenditure trend (Table 3) shows that the state's expenditure increased at a higher pace during the post-AFRBM period compared to the preAFRBM period. The annual growth rate of the total expenditure, however, broadly fluctuated during both the pre-AFRBM period and the post-AFRBM period. Negative growth rates were recorded in 2005-06 and 2015-16, namely 12.38 percent and 8.39 percent, respectively, whereas a significant increase was recorded in 2004-05 and 2009-10, namely 45.49 percent and 43.43 percent, respectively (Figure 3). So, the state's expenditure demonstrated pronounced volatility with occasional shocks. The expenditureto-GSDP ratio also demonstrated a rising trend in the post-AFRBM period.

Of Assam's total expenditure, the revenue expenditure alone accounts for almost 90 percent

Table 2 The tax and revenue GSDP ratios and tax and revenue buoyancy Pre- and post-AFRBM periods

\begin{tabular}{l|ccccc}
\hline \multicolumn{1}{c|}{ Period } & $\begin{array}{c}\text { Own tax-CSDP } \\
\text { ratio }\end{array}$ & $\begin{array}{c}\text { Own revenue - } \\
\text { GSDP ratio }\end{array}$ & $\begin{array}{c}\text { Revenue receipt } \\
\text {-GSDP ratio }\end{array}$ & $\begin{array}{c}\text { Own-tax } \\
\text { buoyancy }\end{array}$ & $\begin{array}{c}\text { Own-revenue } \\
\text { buoyancy }\end{array}$ \\
\hline $\begin{array}{l}\text { The average of } \\
\text { the pre-AFRBM } \\
\text { period }\end{array}$ & 4.23 & 6.24 & 17.69 & 1.12 & 1.39 \\
$\begin{array}{l}\text { The average of } \\
\text { the post-AFRBM } \\
\text { period }\end{array}$ & 5.06 & 7.18 & 20.06 & 1.03 & 1.05 \\
\hline
\end{tabular}

Source: Authors
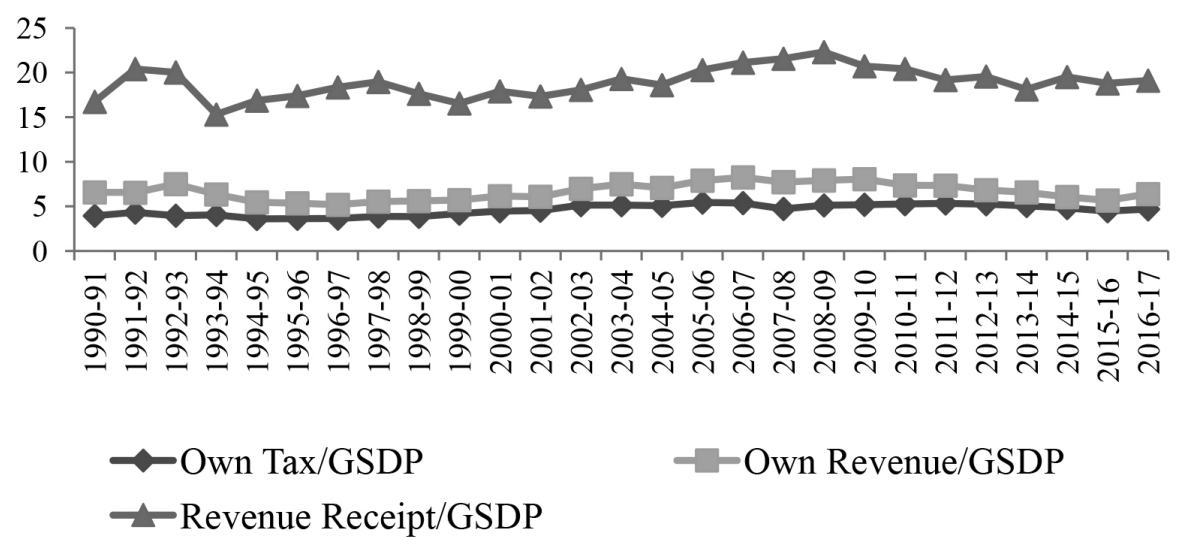

-Own Revenue/GSDP

Figure 2 Assam's own tax, own revenue and revenue receipt as a percentage of the GSDP

Source: Authors 
(Figure 4). Although a marginal decline in the share of the revenue expenditure was noticed from 2005-06 to 2009-10 immediately after the AFRBM act, the share of the revenue expenditure rose again and remained at around 90 percent of the total expenditure. The capital outlay share remained single digit for the largest number of the years in the pre- and postAFRBM periods. The share of the disbursement of loans and advances was minuscule and insignificant, accounting for less than 1 percent of the total expenditure for the largest part of the pre- and postAFRBM periods.

The main factors responsible for the relentless growth of the revenue expenditure are public servants' salaries, interest and pension (retirement benefits), which are called a committed expenditure. The revision of public servants' salaries and wages that takes place at an interval of 10 years according to the recommendation made by the Pay Commission, constituted by the Government, is the most important reason for the increase in the committed expenditure and a sudden jump in the revenue expenditure. The committed expenditure that accounted for 84.52 percent of the revenue expenditure and 102.06 percent of the revenue receipt in 1999-2000 significantly fell in the post-AFRBM period to 58.80 percent and 58.97 percent, respectively, in 2016-17 (Figure 5). The interest payment that accounted for 16.61 percent of the revenue expenditure in 1999-2000 considerably declined to 6.00 percent in 2016-17.

Table 3 Assam's total expenditure trend - in the pre- and post-AFRBM periods

\begin{tabular}{c|cccc}
\hline Year & $\begin{array}{c}\text { Revenue } \\
\text { expenditure }\end{array}$ & Capital outlay & $\begin{array}{c}\text { Disbursement of } \\
\text { loans and advances }\end{array}$ & Total expenditure \\
\hline CAGR pre-AFRBM period & 12.69 & 16.83 & 12.68 & 13.23 \\
CAGR post-AFRBM period & 15.07 & 15.90 & 15.12 & 15.15 \\
\hline
\end{tabular}

Source: Government of Assam, 1991-2016; Reserve Bank of India, 2018

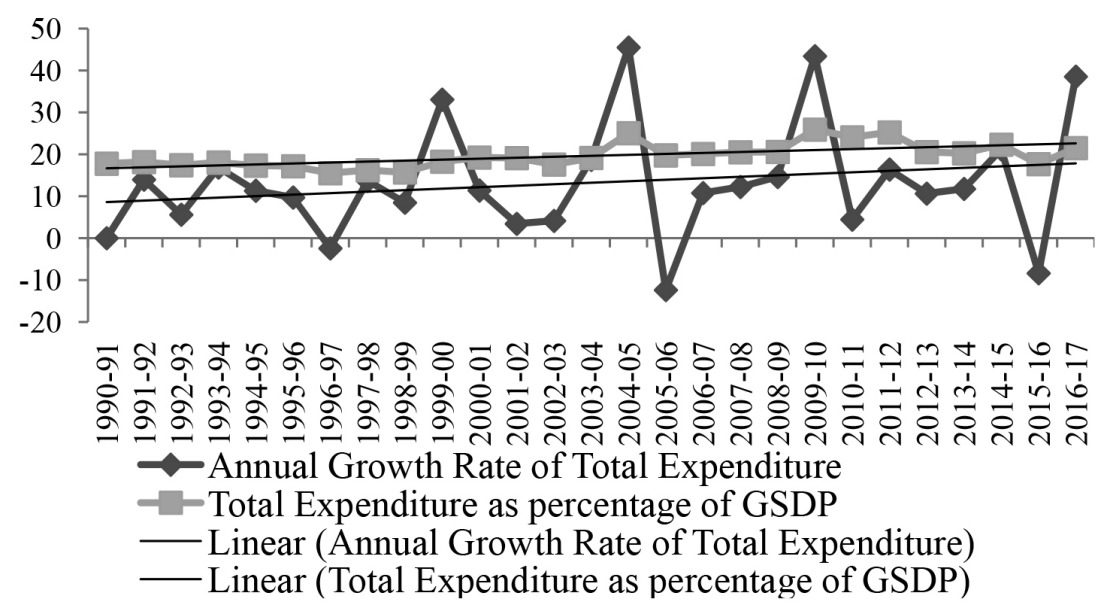

Figure 3 The total expenditure as a percentage of Assam's GSDP and the annual growth rate of the total expenditure

Source: Government of Assam, 1991-2016; Reserve Bank of India, 2018 


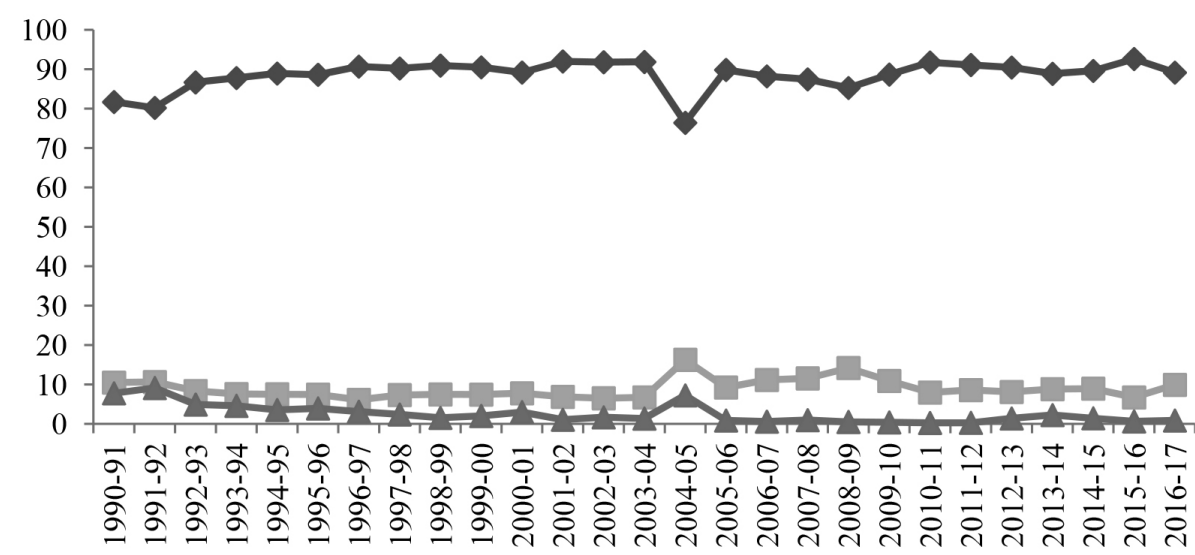

$\rightarrow$ Revenue Expenditure - Capital Outlay $\rightarrow$ Disbursement Of Loans and Advances

Figure 4 The composition of the total expenditure (in percentage)

Source: Government of Assam, 1991-2016; Reserve Bank of India, 2018

\section{Deficit and debt indicators}

The trend of Assam's fiscal deficit, revenue deficit and primary deficit reveals that these deficit indicators remarkably improved during the post-AFRBM period (Figure 6). In the pre-AFRBM period, Assam incurred a moderate fiscal deficit to a huge fiscal deficit, except in 1993-94, when a marginal fiscal surplus was reported. In 1999-2000, Assam incurred 3.34 percent of the revenue deficit and 5.48 percent of the fiscal deficit mainly due to the implementation of the recommendations made by the Fifth Pay Commission on the revision of salaries and wages. However, with the implementation of the AFRBM Act and the fiscal stabilization measures, Assam recorded a revenue, fiscal and primary surplus immediately in 2005-06. The state's government's fiscal restraint allowed the state to earn surpluses in the revenue, fiscal and primary deficits for the next few years, which, however, were distorted in 2009-10 as the state incurred a revenue deficit of 1.92 percent, a huge fiscal deficit of 5.78 percent and a primary deficit of 3.16 percent of the GSDP. The primary reason for this sudden spike in deficits was again due to the implementation of the revision of the salaries and wages according to the recommendations made by the
Sixth Pay Commission. From 2010-11 to 2016-17, the state contained the fiscal deficit to a moderate level, incurred a very marginal revenue deficit only in 201617 , and also earned a primary surplus for a few years. Thus, in the post-AFRBM period, the deficit indicators remarkably improved from 2005-06 to 2008-09, and the state succeeded in achieving a certain degree of fiscal stability thereafter, except in 2009-10.

The state's debt-GSDP ratio fell from 40.87 percent in 1990-91 to 24.88 percent in 1999-2000, only to increase again to 31.92 percent in 2004-05 (Figure 7). After the introduction of the AFRMB Act, Assam's debt-GSDP ratio steadily declined from 30.13 percent in 2005-06 to 18.54 percent in 20016-17. The interest-payment-tothe-revenue-receipt-of-the-state ratio, which was 19.75 percent in 1999-2000, steadily declined to 6.02 percent in 2016-17. These ratios are well below the level of the debt-GSDP ratio of 25 percent, and the interestrevenue receipt ratio of 10 percent recommended by the Fourteenth Finance Commission of India (2014). Thus, in the post-AFRBM period, the debt-GSDP and interest-revenue receipt ratios significantly fell, and the state was able to consistently improve those ratios. 


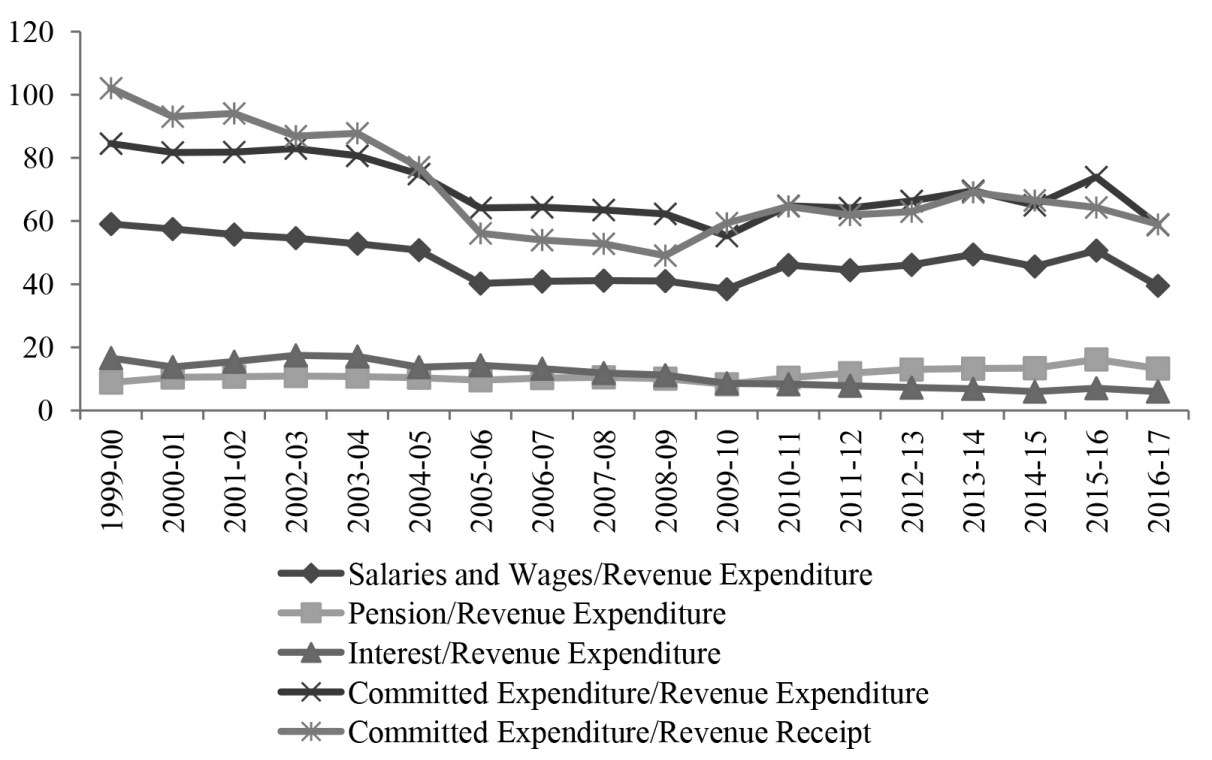

Note: The state data about the salaries and wages are available starting from 1999-2000.

Figure 5 The ratios of the committed expenditure and its components in the revenue expenditure and the revenue Receipt (\%)

Source: Comptroller and Auditor General of India, 2002-2017; Government of Assam, 1991-2016

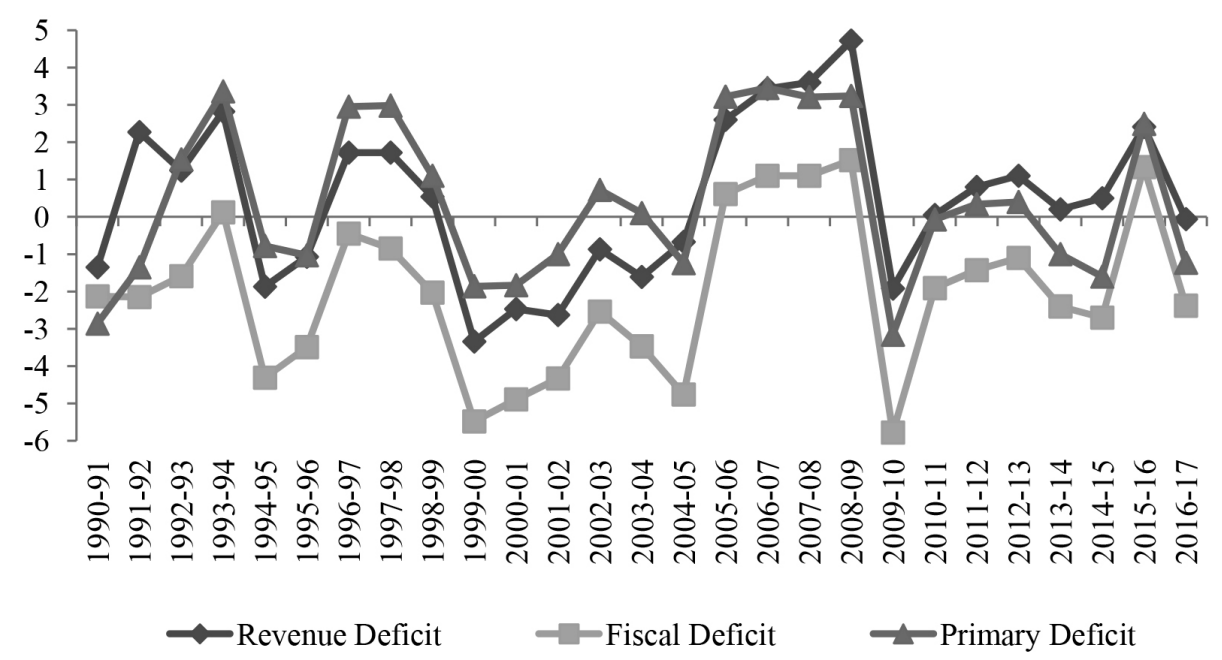

Note: A surplus (+) and a deficit (-)

Figure 6 The trend of the deficit indicators (\%) 


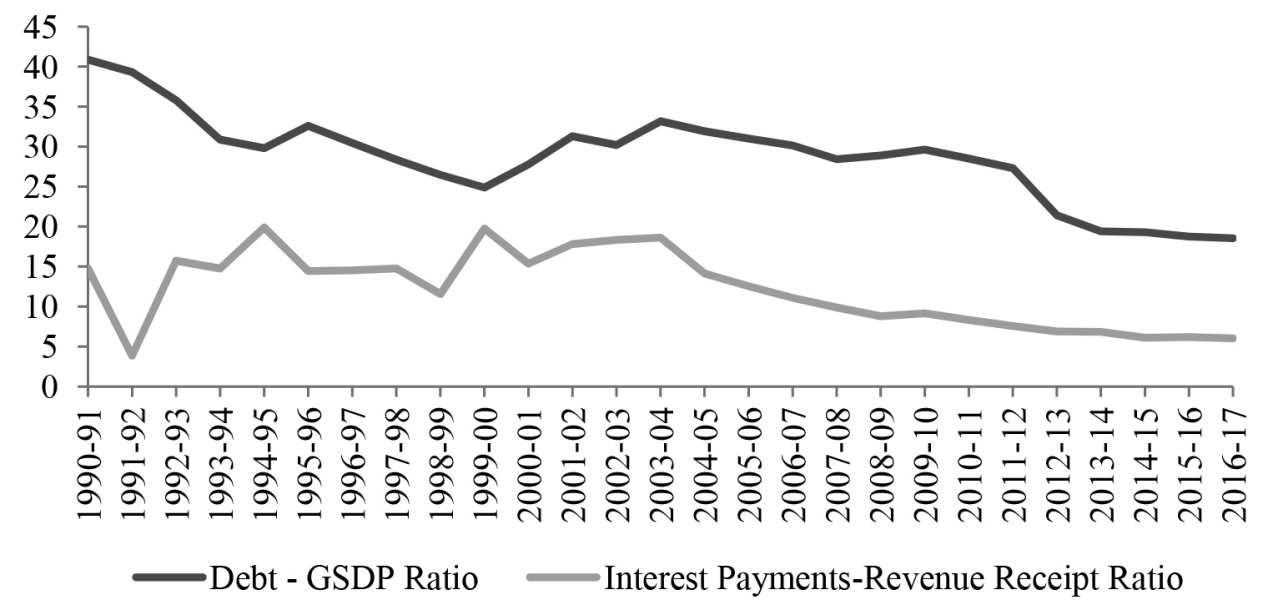

Figure 7 The debt-to-GSDP and interest-to-revenue-receipt ratios

Source: Reserve Bank of India, 2018

\section{CONCLUSION}

The discussion enables us to conclude that the AFRBM Act immensely helped the state to improve the state's deteriorating fiscal situation, and also achieve some degree of fiscal stability. The state was able to make a commendable improvement of its deficit and debt indicators. During the post-AFRBM period, the states' key fiscal indicators almost remained within the boundaries set by the AFRBM Act of 2005 and the AFRBM (Amended) Act of 2011.

Although the fiscal improvement in the post-AFRBM period was being supported by the increase in revenue, that increase was partly a result of significant growth in central transfers. The growth rates in the state's own revenue and the share of the own revenue in the total revenue fell in the post-AFRBM period. With the falling tax-GSDP ratio and increasing dependence on central transfers, it was hard to assert that the revenue side of the state budget improved in the post-AFRBM period.

On the expenditure side, the revenue expenditure still accounts for almost 90 percent of Assam's total expenditure. Although the initial years of the postAFRBM period showed contraction in expenditures, the total expenditure expanded more during the
post-AFRBM period. However, it should be noticed that the share of the committed expenditure in the revenue expenditure and the ratio of the committed expenditure to the revenue receipt significantly declined in the post-AFRBM period, providing the state with some degree of the fiscal space.

The state's capital expenditure did not improve through the study period, only accounting for onetenth of the total expenditure. Thus, the development capital expenditure suffered, which might be due to the fiscal deficit targets of the AFRBM Act. The debtGSDP ratio and the interest payment-revenue receipt ratio being low, the state can take borrowings in order to step up the capital expenditure. Achieving fiscal targets by squeezing developmental expenditure will lead to a more adverse situation. There is a need for a further study to be carried out so as to investigate various sectoral expenditures in order to fully understand the expenditure implications of the AFRBM Act.

The findings of the study are in line with S. Guichard, M. Kennedy, E. Wurzel and C. Andre (2007), the IMF (2009), S. Krogstrup and S. Wälti (2008) and the others claiming that there is a positive association between the fiscal rules and better fiscal outcomes. 


\section{ENDNOTES}

${ }^{1}$ The FRBM Act of 2003 set the elimination of the revenue deficit and the limitation of the fiscal deficit to 3 percent of the GDP by March 31, 2009. In 2009, however, the FRBM Act was suspended for the periods 2009-10 and 2010-11, because of the global financial crisis. In 2011, the FRBM Act was amended by the revised fiscal road map. In 2013, the FRBM Act was again amended, and the revenue and fiscal deficits target dates were revised to March 31, 2015. Again, the Act was amended in 2015 and the target dates were further revised further to March 31, 2018. The Government of India formed a committee in 2016 in order to review the operation and functioning of the FRBM Act.

${ }^{2}$ According to the Maastricht Treaty, the European Union member countries can raise their public debt only up to 60 percent of the GDP and the budget deficit may not exceed 3 percent of the GDP.

${ }^{3}$ Since 1997, the UK had operated the Golden Rule that had only allowed borrowing in order to fund capital spending. The Golden Rule was abandoned in 2009.

4 The Assam Fiscal Responsibility and Budget Management (AFRBM) Act of 2005 was being implemented starting from April 1, 2005, with the goal of eliminating the revenue deficit by 31 March, 2009 and reducing the fiscal deficit to 3 percent of the GSDP by 31 March, 2009. The AFRBM Act was amended in 2011 by the revised fiscal road map. According to the AFRBM (Amended) Act of 2011, the revenue deficit was to be eliminated by 2011-12 and was to contain the fiscal deficit within 3 percent of the GSDP by 2010 and thereafter and maintain it at that level.

\section{ACKNOWLEDGEMENT}

This paper is a result of the research program undertaken at the National Institute of Technology, Mizoram, India. No financial grant of any agency is involved in this research study.

\section{REFERENCES}

Afonso, A., \& Jalles, J. T. (2019). Fiscal rules and government financing costs. Fiscal Studies, 40(1), 71-90. doi:10.1111/14755890.12182

Badaik, S. (2017). Impact of fiscal policy legislations on state finances in India. Theoretical and Applied Economics, 24(3; 612), 115-124.

Barua, N. A., Goswami, N., \& Dutta, P. (2013). Evaluation of state finances: With respect to the state of Assam (A study funded by the Fourteenth Finance Commission of India). Retreieved September 14, 2020, from https://fincomindia. nic.in/writereaddata/html_en_files/oldcommission_html/ fincom14/others/3.pdf

Bergman, M. U., \& Hutchison, M. (2015). Economic stabilization in the post-crisis world: Are fiscal rules the answer? Journal of International Money and Finance, 52(C), 82101. doi:10.1016/j.jimonfin.2014.11.014

Chakraborty, P., \& Dash, B. B. (2017). Fiscal reforms, fiscal rule and development spending: How Indian states have performed? Public Budgeting \& Finance, 37(4), 111-133. doi:10.1111/pbaf.12161

Chakraborty, P., Mukherjee, A. N., \& Amarnath, H. K. (2009). Macro policy reform and sub-national finance: Why is the fiscal space of the states shrinking? Economic and Political Weekly, 44(14), 38-44.

Comptroller and Auditor General of India. (2002-2017). Report of the Comptroller and Auditor General of India on state finances. Government of Assam.

Dutta, P., \& Dutta, M. K. (2014). Fiscal and debt sustainability in a federal structure: The case of Assam in North East India. Romanian Journal of Fiscal Policy, 5(1), 1-19.

Fourteenth Finance Commission of India. (2014). Report of the Fourteenth Finance Commission. New Delhi: Ministry of Finance.

Feld, L., \& Kirchgässner, G. (2001). Does direct democracy reduce public debt? Evidence from Swiss municipalities. Public Choice, 109(3-4), 347-370. doi:10.1023/A:1013077121942

Government of Assam. (1991-2016). Statistical Handbook of Assam. Guwahati, IN: Directorate of Economics \& Statistics. 
Government of Assam. (2008). Memorandum to the Thirteenth Finance Commission of India. Guwahati, IN: Finance Department.

Government of India. (2017). Economic Survey 2016-17. New Delhi, IN: Ministry of Finance.

Grembi, V., Nannicini, T., \& Troiano, U. (2016). Do Fiscal Rules Matter? American Economic Journal: Applied Economics, 8(3), 1-30. doi:10.1257/app.20150076

Guichard, S., Kennedy, M. Wurzel, E., \& Andre, C. (2007). What promotes fiscal consolidation: OECD country experiences. Working Paper No. 5530, ECD Economics Department. doi. org/10.1787/180833424370

Halac, M., \& Yared, P. (2018). Fiscal rules and discretion in a world economy. American Economic Review, 108(8), 23052334. doi:10.1257/aer.20151180

Heinemann, F., Moessinger, M. D., \& Yeter, M. (2018). Do fiscal rules constrain fiscal policy? A meta-regression analysis. European Journal of Political Economy, 51(C), 69-92. doi:10.1016/j.ejpoleco.2017.03.008

IMF. (2009). Fiscal rules: Anchoring expectations for sustainable public finances. Retrieved August 22, 2020, from http://www. imf.org/external/np/pp/eng/2009 /121609.pdf

Kopits, G. (2012). Can fiscal sovereignty be reconciled with fiscal discipline? Acta Oeconomica, 62(2), 141-160. doi:10.1556/ AOecon.62.2012.2.1

Krogstrup, S., \& Wälti, S. (2008). Do fiscal rules cause budgetary outcomes? Public Choice, 136(1/2), 123-138. doi:10.1007/s1l127-008-9285-y

Lahiri, A. K. (2000). Budget deficits and reforms. Economic and Political Weekly, 35(46), 1539-1549.

Maurya, N. K. (2013). Debt sustainability of a sub-national government: An assessment of the state finances of Uttar Pradesh. Working Paper No. 213. Giri Institute of Development Studies.

Misra, B. M., \& Khudrakpam, J. K. (2008). Fiscal consolidation by central and state government: The medium term outlook. Occasional Paper, Mumbai, IN: Reserve Bank of India.

OECD. (2011). Fiscal consolidation: Targets, plans and measures. OECD Journal on Budgeting, 11(2), 15-67. doi. org/10.1787/budget-11-5kg869h4w5f6
Pattnaik, R. K. (2016). Fiscal responsibility and budget management act: An Indian perspective. In C. Singh (Ed.). Public Debt Management: Separation of Debt from Monetary Management in India. Springer. doi:10.1007/978-81-322-36498_8

Raju, S. (2008). Fiscal sustainability analysis of Tamil Nadu. Economic and Political Weekly, 43(30), 131-135.

Rao, M. G. (2004). Linking central transfers to fiscal performance of states. Economic and Political Weekly, 39(18), 1820-1825.

Reserve Bank of India. (2005). Handbook of statistics on Indian economy, 2004-05. Mumbai, IN: Reserve Bank of India.

Reserve Bank of India. (2018). Handbook of statistics on Indian states. Mumbai, IN: Reserve Bank of India.

Reuter, W. H. (2015). National numerical fiscal rules: Not complied with, but still effective? European Journal of Political Economy, 39(C), 67-81. doi:10.1016/j.ejpoleco.2015.04.002

Sacchi, A., \& Salotti, S. (2015). The impact of national fiscal rules on the stabilization function of fiscal policy. European Journal of Political Economy, 37, 1-20. doi:10.1016/j. ejpoleco.2014.10.003

Sawhney, U. (2018). An analysis of fiscal policy in an emerging economy: Innovative and sustainable fiscal rules in India. Millennial Asia,9(3),295-317.doi:10.1177\%2F0976399618805629

Simone, A. S., \& Topalova, P. B. (2009). India's experience with fiscal rules: An evaluation and the way forward. Working Paper No 09/175, IMF. Retrieved September 5, 2020, from https://www.imf.org/external/pubs/ft/wp/2009/wp09175. pdf

Singh, C., Prasad, D., Sharma, K. K., \& Reddy, S. (2017). A review of the FRBM Act. Working Paper No: 550. Bangalore, IN: Indian Institute of Management.

Tapp, S. (2013). The use and effectiveness of fiscal rules in Canadian provinces. Canadian Public Policy, 39(1), 45-70.

World Bank. (2004). State fiscal reforms in India - progress and prospects. Washington, DC: World Bank. Retrived August 19, 2020, from http://documents.worldbank.org/curated/ en/464751468771276830/India-State-fiscal-reforms-in-Indiaprogress-and-prospects

Wyplosz, C. (2012). Fiscal rules: Theoretical issues and historical experiences. Working Paper 17884, National Bureau of Economic Research. 
Received on $22^{\text {nd }}$ November 2020, after revision, accepted for publication on $15^{\text {th }}$ April 2021

Published online on $23^{\text {rd }}$ April 2021.

Santosh Borkakati, MSc, is a research scholar at the Department of the Basic Science and Humanities \& Social Sciences, National Institute of Technology, Mizoram, India.

Konthoujam Gyanendra Singh, PhD, is an associate professor of economics at the Department of the Basic Science and Humanities \& Social Sciences, National Institute of Technology, Mizoram, India. His research interests include conflict, peace and development studies, development economics and economic history. 


\title{
ZAKON O FISKALNOJ ODGOVORNOSTI I PODNACIONALNIM FINANSIJAMA U INDIJI - ANALIZA FISKALNOG SCENARIJA U ASAMU
}

\author{
Santosh Borkakati i Konthoujam Gyanendra \\ Department of Basic Science and Humanities \& Social Sciences, National Institute of Technology, \\ Mizoram, India
}

\begin{abstract}
Zakon o fiskalnoj odgovornosti je postao važan instrument za bolje fiskalno upravljanje i obezbeđivanje fiskalne discipline, naročito u saveznim državama gde su podnacionalne vlade često uključene u aktivnosti koje rezultiraju fiskalnom nedisciplinom. Godine 2003, Indija je usvojila Zakon o fiskalnoj odgovornosti i upravljanju budžetom za ostvarivanje fiskalne discipline, zasnovane na poštovanju pravila, a od indijskih država je, takođe, traženo da iste usvoje svoje sopstveno zakonodavstvo koje se odnosi na fiskalna pravila u skladu sa zakonodavstvom centralne vlade. Kao i država Indija, koja pokazuje znake slabosti u domenu fiskalne odgovornosti, Asam je doneo Zakon o fiskalnoj odgovornosti i upravljanju budžetom (ZAFOUB) 2005, radi boljeg fiskalnog upravljanja. U ovom radu, nastojimo da ispitamo uticaj tog zakona na fiskalne učinke države, analizirajući dinamiku fiskalnih varijabli u periodu pre i posle donošenja tog zakona. Studijom je utvrđeno da je, nakon uvođenja navedenog zakona, ova država ostvarila napredak u domenu fiskalne odgovornosti, i pored pokazatelja da je još uvek sklona sporadičnim fiskalnim šokovima.
\end{abstract}

Ključne reči: fiskalna pravila, podnacionalne finansije, fiskalni deficit, fiskalna stabilnost

JEL Classification: E62, H30, H61, H70 